\section{多 硫酸工場関係}

Lurgi Gessellschaft fur Chemie und Huttenwesen M. B. H.

Warmetechnik Lurgihaus.

Chemibau Dr. Schütt \& Co.
Harpener Bergbau A. G., Kokerei Gneisenau Zinkhütte Nieverheim.

Gebrüder Stumm G. M. B. H., Minister Achenbach.

\title{
Coal Tar Industry in Europe and America
}

\author{
Bý Takashi Yoshidá
}

(The Yawata Iron and Steel Co.)

\begin{abstract}
SYNOPSIS :-The recent developments of coal tar industry and activities of tar research laboratories in Europe and the United States is narrated by the author who visited 80 firms in these countries. The American tar industry is discussed in relation with the iron, coke and coal tar chemicals' industries. The British developments in gas and tar industries are reviewed. Several laboratories in the U. S. and England concerning the lar utilization are outlined. Tar industries in other European countries, West Germany, Belgium, Switzerland and Sweden, are briefly described.
\end{abstract}

\section{石油からオレフインの製造}

一一昭和27年 3 月15日 ペトロケミカルズに関する特別講演会講演—

\section{三菱石油株式会祉 小 幡 武 三}

要旨 筆者はェチレンを目的とする石油分解法の製造裝置, 分解ガスの脫水法, エチレン分離に つき各種の文献を参照して紹介を行い，さらに，技術的見地よりはわが国に招いても石油化学工 業は実施可能であるてとを指摘し，その実現の速かならんととを希望している。

\section{(I) 緒 产}

わたくしは現在実際的製造研究を行つておらず，ま た情に通じておらないので，これらの問題に触れる ことなく，專ら文献から得たものを提示して各位の参 考に供し, 今後先輩各位から種々ご呚示を仰ぎたく念 ずるものである。既に各位がいずれかの文献でご承知 の事項もいろいろあることと思われるが，その点はご 容赦願うこととして話を進めたいと思う。

Sachanen, Eilis, Goldstein, Gluse らの名著書 に述べられているとおり, 炭化水素の分解の際は分解 溫度, 時間, 圧力および使用原料か犬きな係数となる ものであつて,第 1 表に示すと扣り,気相分解法を除く 他の揮発油を目的とする分解法では $\mathrm{C}_{3}$ 以上のォレフ
インは相当量得ることが可能であるが，エチレンを大 量に得ることは困難である。すなわち，その目的とす るところが液休軽質分を多量に得ることであるため， 分解溫度は比較的に低く，加圧下で分解時間を相当長 くするためである。なお，分解ガス中に水素，メタン を相当量含みガス分離作業を困蜼とするため，エチレ ンを目的とする場合は特殊の分解法を探用する必要が 起きてくる。それゆえ以下にはェチレンを主目的とす る製造法について述べることとする。(プロピレン以 上のものを目的とする場合には在来の分解でもその目 的定澾し得るものと思ら。)

\section{（II）エチレン製造の基本的事項}

理論的事項には触れることなく，各実験数等を基本 
第 1 表 各種工業的分解法による生成ガス

A. N. Sachanen, "Conversion of Petroleum" 2nd Ed., p 539.

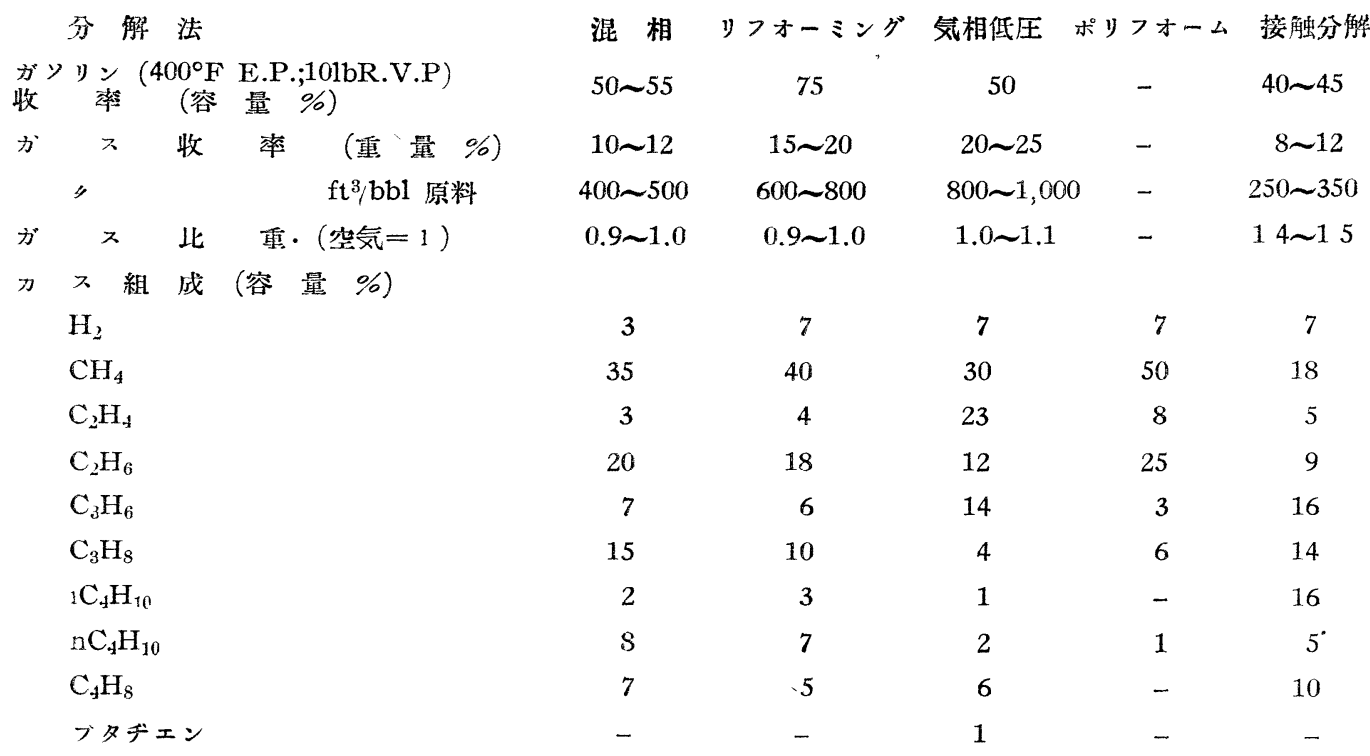

気相 分解 ガ ス 発坐量

B. T. Brooks, Chem. \& Met. Eng., 22, 629 (1920)

$\begin{array}{rr}\text { 分 解 溫度 } & \text { ガ } \\ 580^{\circ} \mathrm{C} & 1,300 \mathrm{ft}^{3} / \mathrm{bbl} \\ 650 \sim 700^{\circ} \mathrm{C} & 2,000 \sim 2,500 \mathrm{ft}^{3} / \mathrm{bbl} \\ 750 \sim 850^{\circ} \mathrm{C} & 3,000 \mathrm{ft}^{3} / \mathrm{bbl}\end{array}$

第2 表 スプレーオイルの各溫度における 気相分解ガス

第 3 表 $n$ 一ヘキサデカン分解の瓜カの関係

(溫度 $500^{\circ} \mathrm{C}$ )

T.F. Groll, Ind. \& Eng. Chem., 25, 784 (1993).

$\begin{array}{llllll}\text { 溫度 }\left({ }^{\circ} \mathrm{C}\right) & 600 & 650 & 700 & 750 & 800\end{array}$ ガス收量(重量\%) $14.2 \quad 45.2 \quad 52.2 \quad 585 \quad 58.0$

組成 (㸚原料油重量\%)

$\begin{array}{lrrrrr}\mathrm{H}_{2} & 0.1 & 0.3 & 0.4 & 05 & 0.7 \\ \mathrm{CH}_{4} & 2.2 & 67 & 10.2 & 15.9 & 16.5 \\ \mathrm{C}_{2} \mathrm{H}_{2} & 0.0 & 0.0 & 0.0 & 0.0 & 0.0 \\ \mathrm{C}_{2} \mathrm{H}_{4} & 4.3 & 13.0 & 16.2 & 21.2 & 24.6 \\ \mathrm{C}_{2} \mathrm{H}_{6} & 1.6 & 3.8 & 4.3 & 5.1 & 4.2 \\ \mathrm{C}_{3} \mathrm{H}_{6} & 3.7 & 11.2 & 134 & 11.3 & 11.3 \\ \mathrm{C}_{2} \mathrm{H}_{8} & 0.4 & 29 & 1.9 & 1.6 & 0.7 \\ \mathrm{C}_{4} \mathrm{H}_{8} & 1.7 & 64 & 5.3 & 2.9 & 0.0 \\ \mathrm{C}_{4} \mathrm{H}_{10} & 0.2 & 0.9 & 0.9 & 0.3 & 0.0 \\ \text { 仝オレフイン } & 9.7 & 306 & 34.9 & 35.4 & 35.9\end{array}$

にして考察することとする。第一に溫度の影響をみる と，使用原料の差違によつて同一溫度でも分解生成物 に差堂は生するが，一例として第 2 表にスプレー・ォ イ几を原料とする場合をみると，溫度か高いほどチ

Voge \& Good, J. Am. Chem. Soc., 71, 594 (1949)

$\begin{array}{llll}\text { 圧 力 } \mathrm{atm} & 1 & 1 & 21\end{array}$

分解率 $42.2 \quad 3150475$

$\mathrm{C}_{2} \mathrm{H}_{4}$ (mol/100mol原料) $\quad 84.0 \quad 769 \quad 14.9$

$\mathrm{C}_{\hat{2}} \mathrm{H}_{6}$ (mol/100mol原料) $\quad 59.0 \quad 474 \quad 271$

液体溜出物中オレフイン(重量\%)

$\begin{array}{cccc}\mathrm{C}_{5} & 94 & 99 & 63 \\ 42 \sim 99^{\circ} \mathrm{C} & 91 & 90 & 69\end{array}$

レンの收量か洺く, $700^{\circ} \mathrm{C}$ 以下てはェチレンの生成揫 か诋い。

次に圧力の影響については，第 3 表に示すと抢り， 加圧下ではその分解率を上昇させても多量のェチレン を得ることか吥可能てあつて，エチレンを目的とする 場合にはできるたけ低圧下で分解を行らことが必要條 件となつてくる。

分解反応時間の影響については，第 1 図に示すと括 り, 高溫分解を行引ほと分解率は上昇与るが最高分解 率を得る反応時間の範团は縮少される。 
分解原料についてみる と，分子量䞄加与るほど 分解溫度が低下し, 最高分 解玄の得られる時間範因が 庢い。または分解溫度力低 いほと最高分解率の得られ る時間範囲が広くなるとも い光る。分解原料による分 解生成物の比較は第 2 図で 行うこととする。眓で見る とおり，原料の分子量力增 大寸るほど分解物のカ ス組 成は複雜となることは，

Rice らの說いているFree Radical Theory なとから 考えて皮諒解のできること てめつて，実際作業につい ても原料選択上注意すべき 事項であると考灾ている。 しかしながら，低分子量の 原料か良いといらても，第 1 図でちよつと触れたと特 り，分解溫度などの関係て 設備の材料その他を考慮し て，扮の竹のの分解恒数な との考察をひとと物りは行 つて扔くべきことだと思 5。以上をるつてェチレン 分解の基本的常識としての 說明を終る。

\footnotetext{
（III）エチレン製造の実裝置について
}

米国に知いていかなる型式のるのが般に探用され
第1図 エタンおよびプロパンのエチレン分解の溫度, 反応時間の影響 Sullivan, Ruthruff \& Kuenzel, Ind. \& Eng. Chem., 27, 1072 (1932).
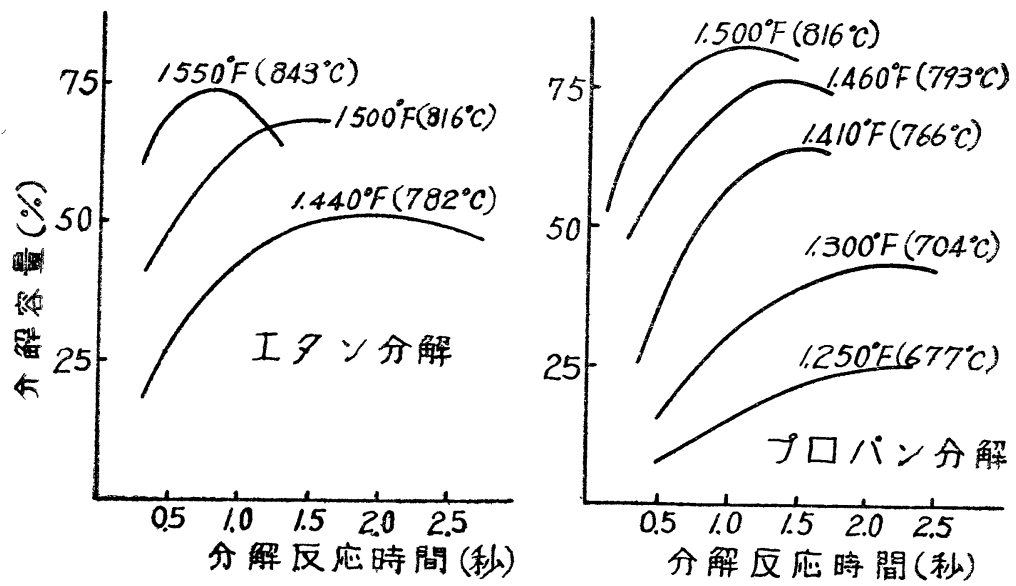

第 2 図繁エタン, プロパンのエチレン分解

H. C. Shutt, Chem. Eng. Progress, 43, 103 (1947).
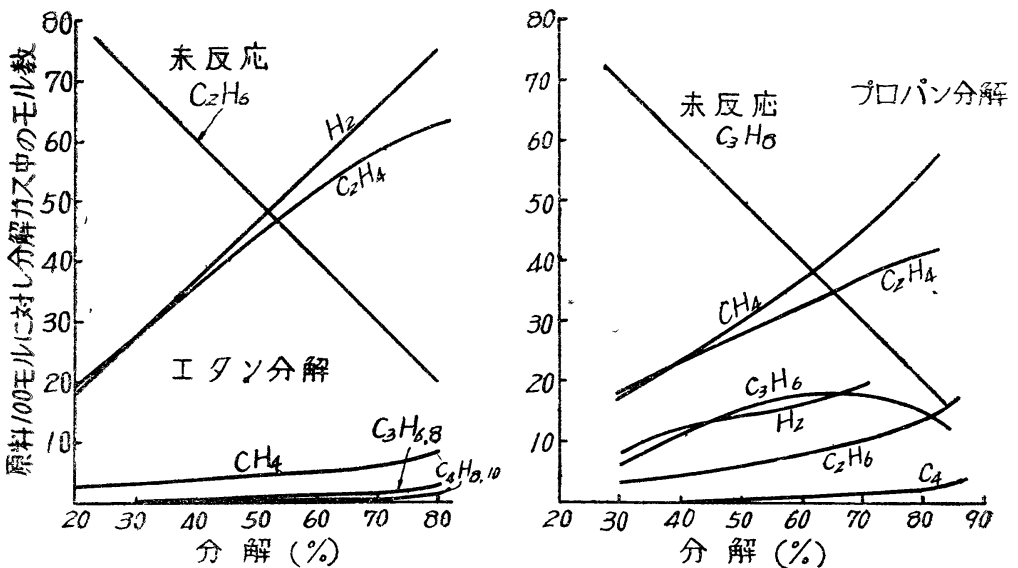

第 4 表 米国におけるる代表的エチレン製造工場（1949 年現在）

Oesman, "Encyclopedia of Chemical Ind."

番骂

Carbide \& Carbon Chemical Corp.

1 A So. Charleston W. Va.

- C Texas City, Texas

(Dow Chemical Co.

2 A Midland, Mich

B Velasco, Texas

3 Du-Pont Co. Orange, Texas

4 Ethyl Corp. Baton Rouge, La.

5 Jefferson Chem. Port Neches, Texas

6 Koppers Co. Kobuta, Pa.
裝置名

プロパン

コイル・クラッキン低溫高压分離法 グ

蓄熱炬原油分解

プロパン・コイル・

クラッキング

プロパン・コイれ・

クラッキング

?

エタン,プロパン・コ

イル・クラッキング

軽油・ペツグルヒー

ター・クラッキング
ガ、ス分離法

$1,100,000$

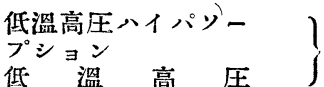

230,000

低溫吸收

低溫高圧

150,000

低溫吸收

40,000

190,000

10,000 
Monsant Chem Texas City, Texas

Phillip Petr. Co. Borger, Texas

9 Shell Chemical Houston, Texas

10

Standard Oil Co. Baton Rouge, La.

11

Wyandotte Chem. Wyandotte, Mich.
エ夕ン・燯融鍇分解

エタン、プロパン・コ

イル・タラ・キング

ブロパン，俥湡・コ

イル・クタッキング

ナフサ，軽油・コイ

ル・タランキング
170,000

高圧吸 收 230,000

些溫高圧

400,000

375,000

45,000
はできないが，その大勢を察することは可能でする。

その規格についてみると，シェルの 200t/日を最大 として小はコッパースの 10t/日と各種の大きさのむ のがある。分解方式はコイル・クラッキングが压倒的 に多く，原料はプロパンを使用するものが多い。ガス の分離法は低溫高压法とと低溫吸收法を探用するもの
が多く、ハイパー・ソープションを使用しているのは ダウ・ケミカルだけである。

（IV） エチレン製造を目的とする分解法

（1）ルンマス型コイル式ェチレン製造裝置

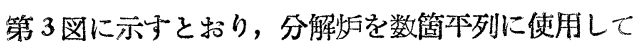
いることを特徵とするもののよらてあつて，分解畤間

第3図 ルンマス型コイル式エチレン製造法

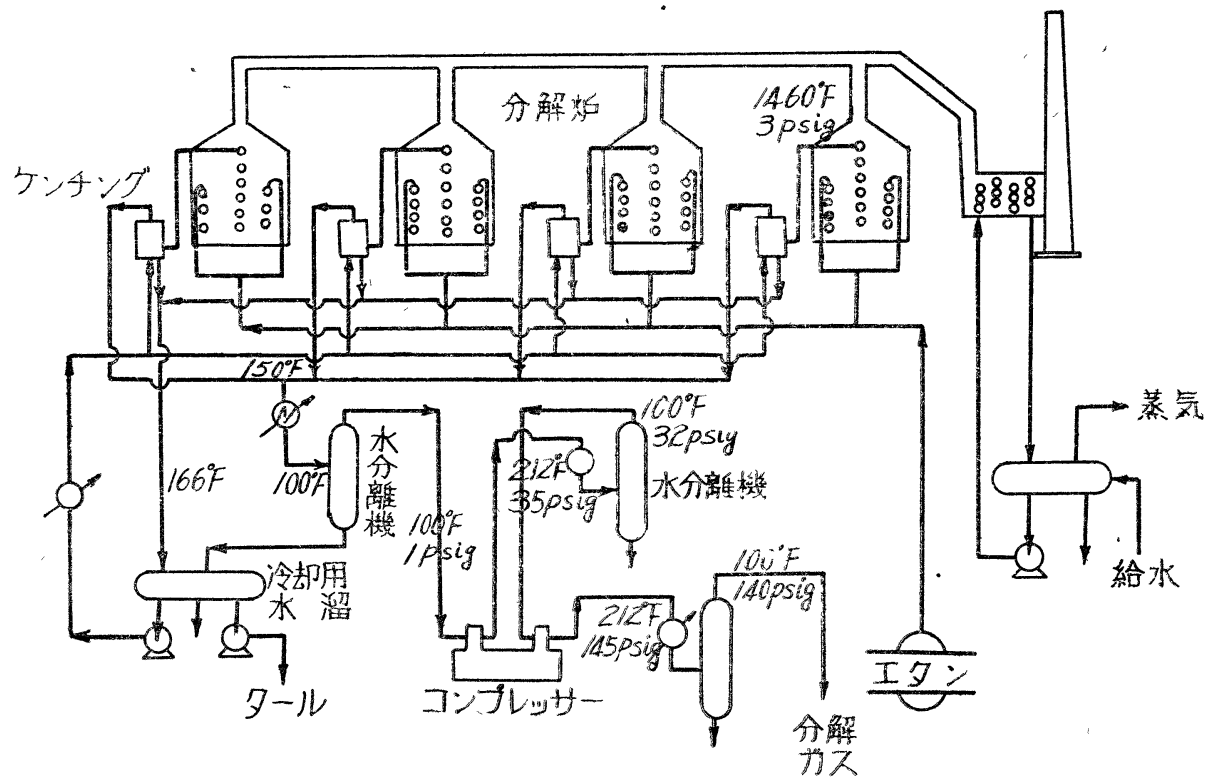

第 4図 ホスターホイラー型コイル式エチレン製造裝置

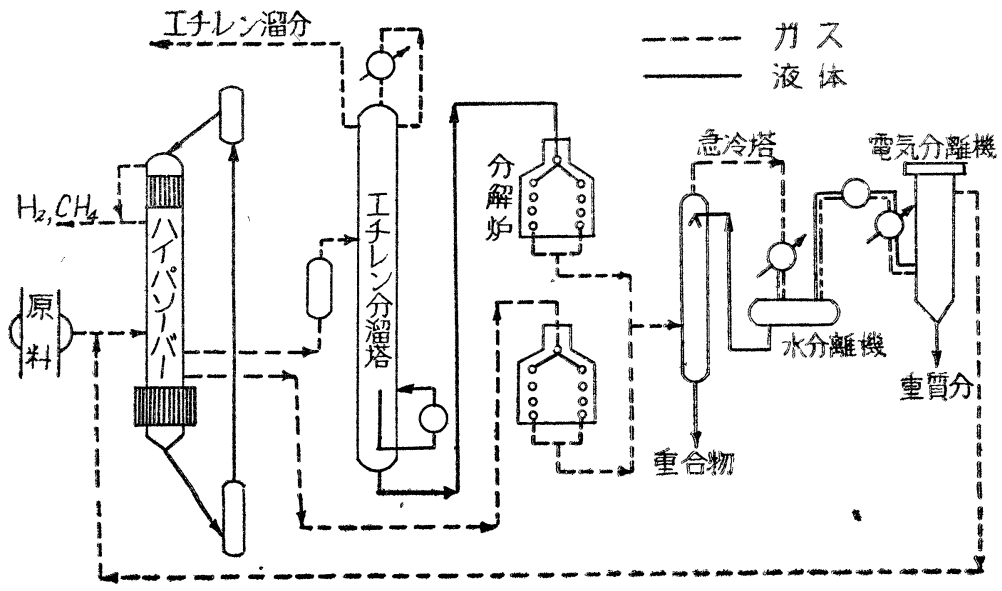

を中心に考慮して設計され ているもののように思われ る。分解物の急冷は $150^{\circ} \mathrm{F}$ まで一段で行つていること も特徵の一うとみることも できると考えられる。

(2) フォスターホイラ

一型コイル式エチレン

製造裝置

本法の大略系統図は第 4

図に示すと招りであつて， ルンマス型との差違は, 原 料をまずハイパソーバーで 分子量の異るェタン溜分と 
プロパン溜分との2つに分 離し，これを別々に分解す るようになつている点と急 冷塔を別に設けている点で あると思われる。

(3) ケロッグ型コイル式 エチンン製造裝置

最近ケロッグ会社で英国 その他に建設した型式のも ので第 5 図がその說明書か ら得た想像系統図である。 特徽とするところは，原料 加熱站の資材および炭化水 素の分解機構に特別の考慮 を払い，原料加熱岾で原料 の加熱を $1300^{\circ} \mathrm{F}$ 程度にと どめ，別に $2000^{\circ} \mathrm{F}$ に加熱 された過熱蒸気，大体原料 炭化水素に対し重量で 3 倍程度, を分解室でこれに混 合して分解溫度を $1700^{\circ} \mathrm{F}$ 近くにして分解を行うこと とトランスファー・ライシに急泠水を入れて $900^{\circ} \mathrm{F} に$ 急冷し，次に油分離塔および氷分離塔で分解物を 2 段 に冷却していることである。詳細は不明であるが，こ の型式のものが最も進步した合理的のものでないかと 思われる。

\section{（4）コイル式ェチレン製造装置の一般概念}

前述したと和り，ェチレン製造については，分解反 㐫時間の短いことと圧力を低くすることを第一條件と されるため, 分解加熱版の大さはある程度の制約を受 けることとなる。H. C. Shutt は加熱管の內徍は4in を最大としている。簡単な分解加熱脈の設計基本とな るものの一部を示すものが第 5 表である。なお，加熱 管は高溫にさらされるため高ニッケル合金鋼の使用を

\section{第 5 表 コイル式エチレン製造加熱管流速 (エタン, プロパン分解)}

H. C. Shutt, Chem. Eng. Progress, 43, 103 116

(1947).

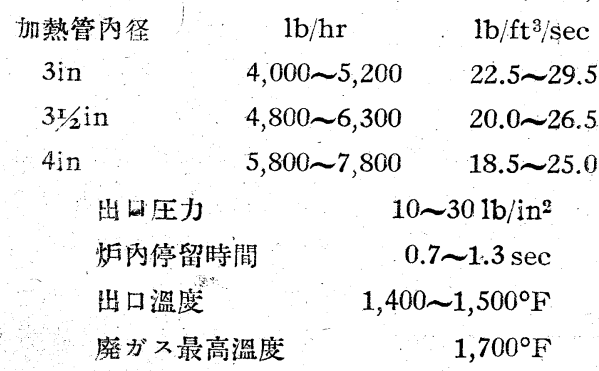

望さところであるが，=ッケルが炭化水素の脫水素触 架として作用して加熱管中に炭素の沈積することが多 くこの点でも材料的の制約を受けるとのことであ る。

典型のキイル式ェチレン製造法による分解製品の一 例として第6表を示す。エタンなたはプロパンを原料 とした場合には，大体容量\%で 20\% 内外のエチレン が得られる見込みである。

\section{第 6 表 コイル式エチレン製造法分解製品}

H. C. Schutt, Chem. Eng. Progress, 43, 103 116 (1947).

原料名 エタンエタン プロパン 加熱管出口溫度 ${ }^{\circ} \mathrm{F} \quad 1,425 \quad 1,475 \quad 1,435$ 压力 $1 \mathrm{~b} / \mathrm{in}^{2} \quad 30.0 \quad 15.6 \quad 15.0$ 反店時間 $\mathrm{sec} \quad 1.05 \quad 1.50$ -

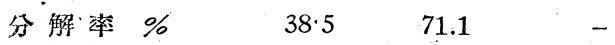
分解製品組成（容量\%)

$\begin{array}{lrrr}\mathrm{H}_{2} & 26.0 & 40.8 & 9.4 \\ \mathrm{CH}_{4} & 2.5 & 2.9 & 21.9 \\ \mathrm{C}_{2} \mathrm{H}_{4} & 25.5 & 36.5 & 19.7 \\ \mathrm{C}_{2} \mathrm{H}_{6} & 46.2 & 17.2 & 0.5 \\ \mathrm{C}_{3} \mathrm{H}_{6} & 0.2 & 0.6 & 24.5 \\ \mathrm{C}_{3} \mathrm{H}_{8} & - & 0.3 & 0.6 \\ \mathrm{C}_{4} & 0.3 & 0.5 & 1.7 \\ \mathrm{C}_{5} & 0.1 & 0.7 & 10.5\end{array}$

前にケロッグ型のものの場合に蒸気を吹达むと述べ たが，分解の際空気または蒸気を通じた場合につい 
てオレフイン生成量の差違を示すむのとして第 7 表 を示す。ここては，分解度の强さの等しいものの比較
さするための標準として, $\mathrm{C}_{2}: \mathrm{C}_{3}+\mathrm{C}_{4}$ の比をもつこ している。本表てみた場合に，蒸気と空気を併用吹込

\section{第 7表 コイル式エチレン箐造法作業方式の差違による比較}

D. M. Rudkovski1, V. G. Marıkovich \& B. A. Kozakova, $f$ of Appred Chemistry (U.S.S.R), 19, 1381 92 (1946) (原料 Saratov 分解重油)

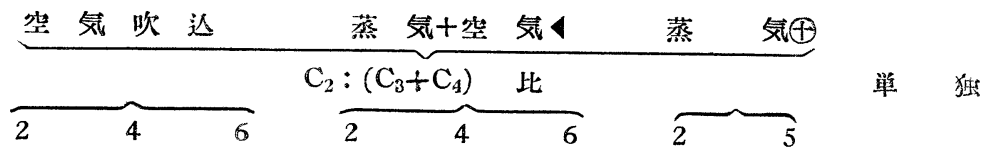

対原料油 (重 量 \%)

$\begin{array}{lrrrrrrrrr}\mathrm{C}_{4} \mathrm{H}_{8} & 1.5 & 1 & 0.2 & 3.5 & 2.5 & 1.0 & 3.6 & 11 & - \\ \mathrm{C}_{4} \mathrm{H}_{6} & - & - & - & 2.5 & 1.5 & 08 & 1.3 & - & - \\ \mathrm{C}_{3} \mathrm{H}_{6} & 5.5 & 4 & 2.5 & 5.0 & 3.5 & 2.0 & 6.2 & 4.1 & - \\ \mathrm{C}_{2} \mathrm{H}_{4} & 9.0 & 11.5 & 12.5 & 12.5 & 14.0 & 10.5 & 109 & 13.0 & 9 \sim 10 \\ \text { 全オレフイン } & 160 & 16.5 & 15.2 & 23.5 & 21.5 & 143 & 220 & 18.2 & 11 \\ \mathrm{H}_{2} & 0.3 & 0.6 & 1.0 & 0.5 & 0.9 & 1.2 & 0.5 & 0.8 & - \\ \mathrm{CH}_{4} & 12.0 & 12.5 & 11.5 & 8.0 & 11.0 & 10.0 & 5.5 & 85 & - \\ \text { 乙 } & & & & & & & \end{array}$

ガ ス 組 成 (容 量 $\% *)$

\begin{tabular}{|c|c|c|c|c|c|c|c|c|}
\hline $\mathrm{C}_{4} \mathrm{H}_{8}$ & 12 & 0.7 & 0.2 & 2.6 & 1.0 & 0.5 & 4.0 & $04-$ \\
\hline $\mathrm{C}_{3} \mathrm{H}_{6}$ & 5.0 & 2.8 & 2.0 & 5.0 & 3.0 & 15 & 11.4 & 58 \\
\hline $\mathrm{C}_{4} \mathrm{H}_{6}$ & - & - & - & 1.6 & 0.5 & 0.2 & 1.3 & - \\
\hline $\mathrm{C}_{2} \mathrm{H}_{4}$ & 13.0 & 16.5 & 16.0 & 20.0 & 19.0 & 15.0 & 305 & 30.2 \\
\hline $\mathrm{H}_{2}$ & 7.0 & 13.2 & 19.5 & 12.5 & 18.0 & 23.5 & 200 & 247 \\
\hline $\mathrm{CH}_{4}$ & 28.7 & 29.0 & 28.5 & 22.5 & 29.0 & 260 & 25.1 & 353 \\
\hline 原料よりガス收量 $\quad(l)$ & 25 & 34 & 33 & 30 & 42 & 39 & 26 & 33 \\
\hline
\end{tabular}

分解油（対原料重量％)

$\begin{array}{lrrrrrrrrr}200^{\circ} \mathrm{C} \text { 以下溜出油 } & 7.3 & 11.8 & 7.4 & 5.0 & 7.4 & - & 9.3 & 14.6 & - \\ \text { ベンゼン } & 2.0 & 4.4 & 35 & 0.9 & 2.6 & - & 1.0 & 1.9 & 45 \\ \text { トルメン } & 12 & 0.9 & 0.7 & 0.4 & 1.1 & - & 0.7 & 1.0 & 1.1 \\ \text { キシレン } & 0.4 & 06 & 0.2 & 0.3 & 0.3 & - & 0.2 & 06 & 06 \\ \text { ベ芳香族 } & 3.6 & 5.9 & 4.4 & 16 & 4.1 & - & 1.9 & 35 & 6.2 \\ \text { コークス } & 67 & 11.7 & 12.5 & 3.7 & - & 3.4 & 4.6 & 85 & 16 \sim 18\end{array}$

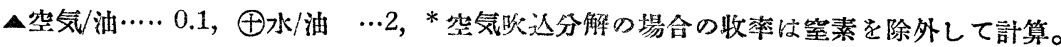

の場合最むェチレンの收量が多いこととなつていて， 蒸気吹込かにれに次いている。空気吹込については， パー・パスについての分解率か良いから循環量か沙な くてすむため分解裝置は小さくでむという意見と， 分解ガス中の跮素（空気中）の分離の不利をあげてこ れに反対する意見との両面の見方をされている。炭化 水素分解の場合の酸素および水の反灾については第 8 表および第 9表を示す。第9表に見られるよらに, 一

第 8 表 空気吹还によるパラフイン分解機棈 Peace, J. Am. Chem. Soc., 51 1839,905 (4929) *レフイン $\left\{\begin{array}{l}\mathrm{C}_{3} \mathrm{H}_{6}+0.5 \mathrm{O}_{2} \rightarrow \mathrm{C}_{3} \mathrm{H}_{6}+\mathrm{H}_{2} \mathrm{O} \\ \mathrm{C}_{2} \mathrm{H}_{6}+0.5_{2} \mathrm{O} \rightarrow \mathrm{C}_{2} \mathrm{H}_{6}+\mathrm{H}_{2} \mathrm{O}\end{array}\right.$ フルデヒド $\mathrm{C}_{3} \mathrm{H}_{\delta}+2 \mathrm{O}_{2} \rightarrow \mathrm{CO}+2 \mathrm{H}_{2} \mathrm{O}+\mathrm{CH}_{3} \mathrm{CHO}$

\section{第 9 表 オレフイン類製造の場合の水の作用}

伋 定 $\mathrm{C}+2 \mathrm{H}_{2} \mathrm{O} \rightarrow \mathrm{CO}_{2}+2 \mathrm{H}_{2}$

$$
\begin{aligned}
& \mathrm{C}+\mathrm{H}_{2} \mathrm{O} \rightarrow \mathrm{CO}+\mathrm{H}_{2} \\
& \mathrm{CH}_{4}+\mathrm{H}_{2} \mathrm{O} \rightarrow \mathrm{CO}+3 \mathrm{H}_{2} \\
& \mathrm{CH}_{4}+2 \mathrm{H}_{2} \mathrm{O} \rightarrow \mathrm{CO}_{2}+4 \mathrm{H}_{2} \\
& \mathrm{CO}+\mathrm{H}_{2} \mathrm{O} \rightarrow \mathrm{CO}_{4}+\mathrm{H}_{2} \\
& \mathrm{CnH}_{2} \mathrm{n}+2 \mathrm{H}_{2} \mathrm{O} \rightarrow \mathrm{CO}+(2 \mathrm{n}+1) \mathrm{H}_{2}
\end{aligned}
$$

D. M. Rudkovsk11 “High Temp. Py,olyses $O_{22-}$ dation of Fuels as Technical Method for Produscing Gaseons Olefins"

反店溫度 ${ }^{\circ} \mathrm{C} \quad 900 \quad 980 \quad 1055 \quad 1080$ 水/油此 $3.3 \quad 3.6 \quad 2.9 \quad 4.6$ $\begin{array}{lllll}\text { 水火㸹する反応水\% } & 0.5 & 1.3 & 48 & 4.5\end{array}$ 
芯水多化学反匛にあすかるものと思われるが，実際上 は極く僅少の水分か汳忘後に減少している程度であつ て, 詳細は不明であるが，水は直接反灾にあづからず 大体オンフィンの重合防止と水素濃度を下げるといら たような役目をしているのではなからうかとの意見か 出されている。

（5）ペノプル・ヒーター・エチレン製造装置

いわゆる T.P.C. 法として一般に紹介されているも のである。大体の系統図は，第6図に示すと打り T.

C.C. とよく似た型式の 第6図 ペップルヒータ ものて，熱の媒体として ペッブルを使用して值接 加熱することを特徵とし ている。したからて，加 熱盜度，時間の調整か洎 由であつて，理論的には 有望な方法であるよらに 考えられるか，実裝置と して建設されているるの が少ないことは種々機械 的難点があるためであろ 5と思万。
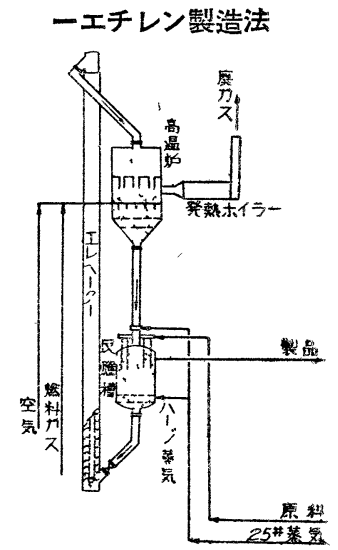

本洗による分解成生物その他を示すのが第 10 表で
第10表 ペッブル・ヒーター・エチレン製造法の性能

S. C. Eastwood, A. E. Potas, Petı. Eng., Aug.

(1948)

\begin{tabular}{|c|c|c|c|c|c|}
\hline \multirow{3}{*}{ 原 } & \multicolumn{3}{|c|}{ Once through } & \multicolumn{2}{|c|}{ リサイクル分解 } \\
\hline & \multicolumn{2}{|c|}{ エタைン } & \multirow{2}{*}{ 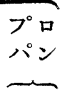 } & \multicolumn{2}{|c|}{ 混合ガス } \\
\hline & & & & 張込 & サイク \\
\hline $\mathrm{CH}_{4}+\mathrm{H}_{2}$ & & & & 0.8 & - \\
\hline $\mathrm{C}_{2} \mathrm{H}_{6}$ & \multicolumn{2}{|c|}{$99+$} & & 40.8 & 684 \\
\hline $\mathrm{C}_{3} \mathrm{H}_{8}$ & & & $99+$ & 40.0 & 14.4 \\
\hline $\mathrm{C}_{3} \mathrm{H}_{6}$ & & & & 16.0 & 22.0 \\
\hline \multirow[t]{2}{*}{$\mathrm{C}_{4}$} & & & & 2.4 & - \\
\hline & & & & 100.0 & 100.0 \\
\hline 溫 度 ${ }^{\circ} \mathrm{F}$ & $\overparen{1525}$ & 1770 & 1510 & \multicolumn{2}{|c|}{1500} \\
\hline 接触時間 sec & 2.3 & 0.12 & 1.2 & \multicolumn{2}{|c|}{17} \\
\hline 循環比 (重量) & - & - & - & \multicolumn{2}{|r|}{1.0} \\
\hline \multicolumn{6}{|c|}{ 剂原料收率 （重量\%） } \\
\hline $\mathrm{H}_{2}$ & 5.7 & 5.7 & 2.0 & \multicolumn{2}{|c|}{3.2} \\
\hline $\mathrm{CH}_{4}$ & 12.8 & 102 & 262 & \multicolumn{2}{|c|}{23.2} \\
\hline $\mathrm{C}_{2} \mathrm{H}_{2}$ & 0.7 & 3.8 & 0 & \multicolumn{2}{|r|}{0} \\
\hline $\mathrm{C}_{2} \mathrm{H}_{4}$ & 49.2 & 56.2 & 37.5 & \multicolumn{2}{|c|}{62.0} \\
\hline $\mathrm{C}_{2} \mathrm{H}_{6}$ & 18.2 & 116 & 35 & \multicolumn{2}{|r|}{ - } \\
\hline $\mathrm{C}_{3} \mathrm{H}_{6}$ & 0.7 & 1.0 & 12.2 & \multicolumn{2}{|r|}{ - } \\
\hline $\mathrm{C}_{3} \mathrm{H}_{8}$ & 1.1 & 0.7 & 7.9 & & - \\
\hline
\end{tabular}

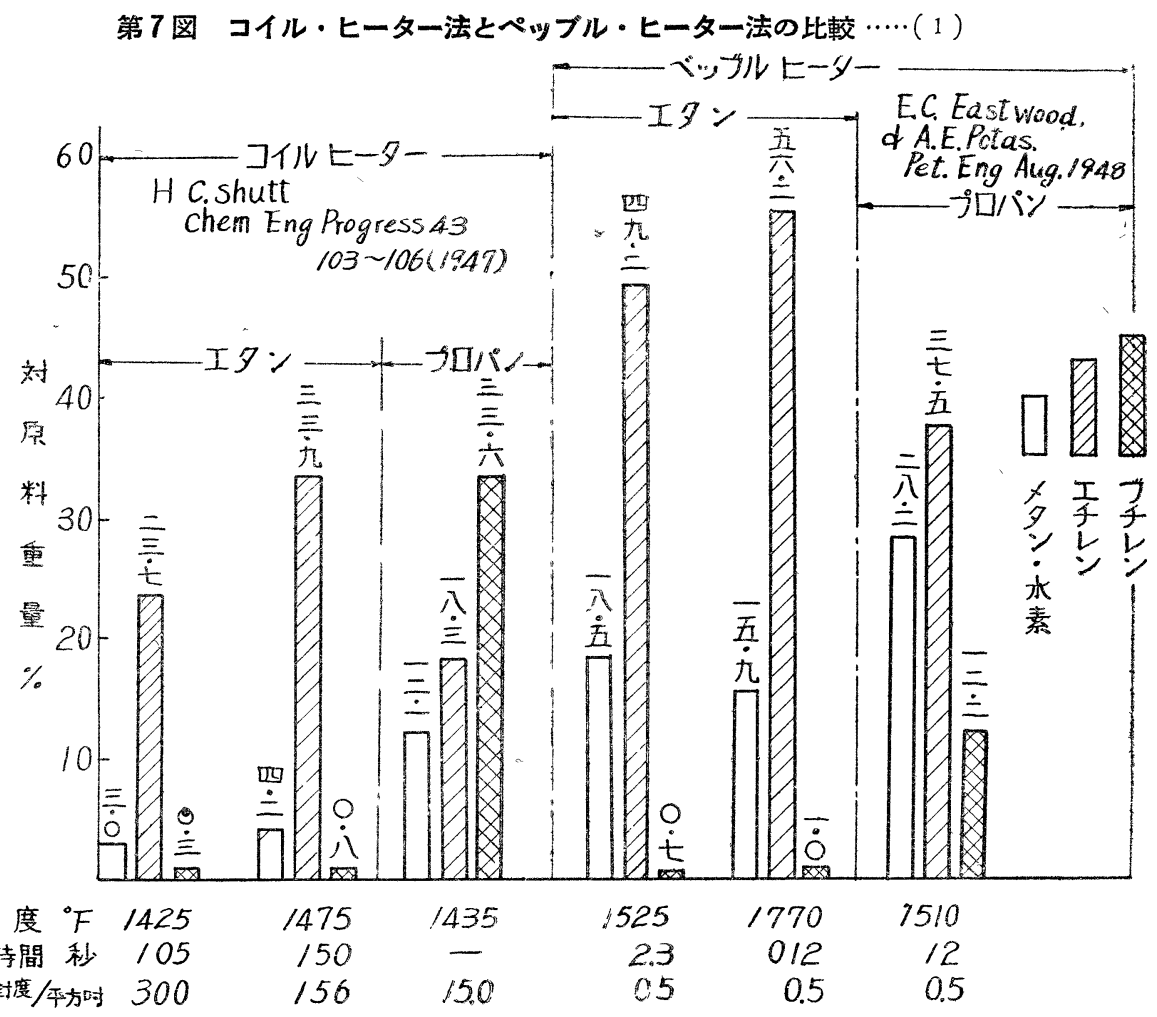




\begin{tabular}{|c|c|c|c|c|}
\hline ブタヂェン & 1.6 & 3.2 & 2.8 & \\
\hline $\mathrm{C}_{4} \mathrm{H}_{8}$ & 1.8 & 0.4 & 1.1 & \\
\hline $\mathrm{C}_{4} \mathrm{H}_{10}$ & 1.0 & 0.3 & 0 & \\
\hline $\mathrm{C}_{5}+$ & 6.7 & 6.1 & 6.8 & \\
\hline エークス & 0.5 & 08 & 0.5 & \\
\hline 合 計 & 100.0 & 100.0 & 100.0 & 100 \\
\hline $\begin{array}{l}\mathrm{C}_{2} \text { 以下溜分中 } \\
\mathrm{C}_{2} \mathrm{H}_{4} \text { mol \% }\end{array}$ & 29.0 & 33.3 & 32.7 & 30 . \\
\hline \multicolumn{4}{|l|}{ 装置性能 } & \\
\hline ペッブル & 原料比 & 重量) & $10 \sim 20$ & \\
\hline 加熱溫度 & ${ }^{\circ} \mathrm{F}$ & 1,40 & $00 \sim 1,800$ & \\
\hline 接触時間 & sec & & $0.1 \sim 2.5$ & \\
\hline 圧 力 & & & 0.5 & \\
\hline 蒸気吹达量 & 対原粎 & $\$ \%$ & $0 \sim 50$ & \\
\hline
\end{tabular}

第11表 コイル・ヒーター法とペップル・ヒーター法 の比較 ….(2)

加熱溫度 ${ }^{\circ} \mathrm{F}$

接触時間 sec

压 力 $1 \mathrm{~b} / \mathrm{in}^{2}$

廃ガス溫度

最大能力 $1 \mathrm{~b} / \mathrm{hr}$

(エタン，プロパン)

$$
\begin{gathered}
\text { コイル. } \\
\text { ヒーダー } \\
1,400 \sim 1,500 \\
0.7 \sim 1.3
\end{gathered}
$$$$
1,400 \sim 1,800
$$$$
10 \sim 30
$$

$1,700^{\circ} \mathrm{F}$ 以下

$0.1 \sim 2.5$

0.5 以上

$5,800 \sim 7,800$

ある。本表はパイロット・プラント試験による結果て あるが，エチレン收量は多いが，水素，メタンの生成 量が多いという弱点があるものと考えられる。参考ま でにコイル・ヒーターとペッブル・ヒーターの比較を

概念的に示すむのとして第7図，第11表を示すことと 寸る。

（6） U.O.P. 型 Autothermic エチレン製造裝置 系統図は第8図に示寸と和り，原料力不空気を混 合して $1,700 \sim 1,800^{\circ} \mathrm{F}$ で直接酸化を行うものてむる。 高溫部か湅瓦張りて施工し得られるから材料的には比 較的に楽であると考兵られるが，分解物中にはアセチ レンを含もため，ガス分離前にアセチレンに水添を行 ろ要がある。分解物については第12表に示すと招り である。

\section{第12表 Autothermic エチレン製造法分解ガス}

原料 エター プ $37 / 63$

料 × タン プロパン

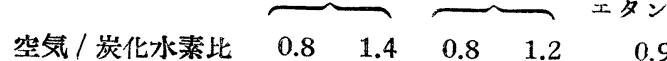

$\begin{array}{lllllll}\text { 分 解率 } & 52.6 & 81.8 & 48.1 & 79.5 & 78.0\end{array}$

$\begin{array}{llllll}\mathrm{H}_{2} & 15.8 & 19.8 & 8.8 & 9.6 & 183\end{array}$

$\begin{array}{llllll}\mathrm{CH}_{4} & 2.7 & 5.9 & 11.0 & 17.3 & 19.0\end{array}$

$\begin{array}{lllllll}\mathrm{C}_{2} \mathrm{H}_{2} & 0.05 & 0.3 & 0 & 0.3 & \text { 痕 跡 }\end{array}$

$\begin{array}{llllll}\mathrm{C}_{2} \mathrm{H}_{4} & 19.6 & 21.3 & 12.5 & 18.0 & 16.7\end{array}$

$\begin{array}{llllll}\mathrm{C}_{2} \mathrm{H}_{6} & 22.1 & 6.6 & 0.8 & 1.1 & 5.3\end{array}$

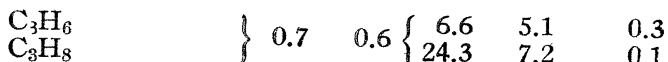

$\left.\mathrm{C}_{3} \mathrm{H}_{8} \quad\right\} \quad \begin{array}{lll}24.3 & 7.2 & 0.1\end{array}$

$\begin{array}{llllll}\mathrm{C}_{\text {s }} & 0.05 & 0.4 & 0.8 & 1.1 & 0.2\end{array}$

$\begin{array}{llllll}\mathrm{C}_{5} & - & 0 & 0 & 0.1 & 0\end{array}$

$\begin{array}{llllll}\mathrm{CO} & 2.1 & 4.5 & 4.2 & 4.9 & 5.5\end{array}$

$\begin{array}{llllll}\mathrm{CO}_{2} & 2.8 & 2.3 & 2.1 & 2.5 & 2.1\end{array}$

$\begin{array}{llllll}\mathrm{N}_{2} & 34.1 & 38.3 & 28.3 & 328 & 32.5\end{array}$

第 8 図 U. O. P. 型 Autothermic エチレン製造裝置

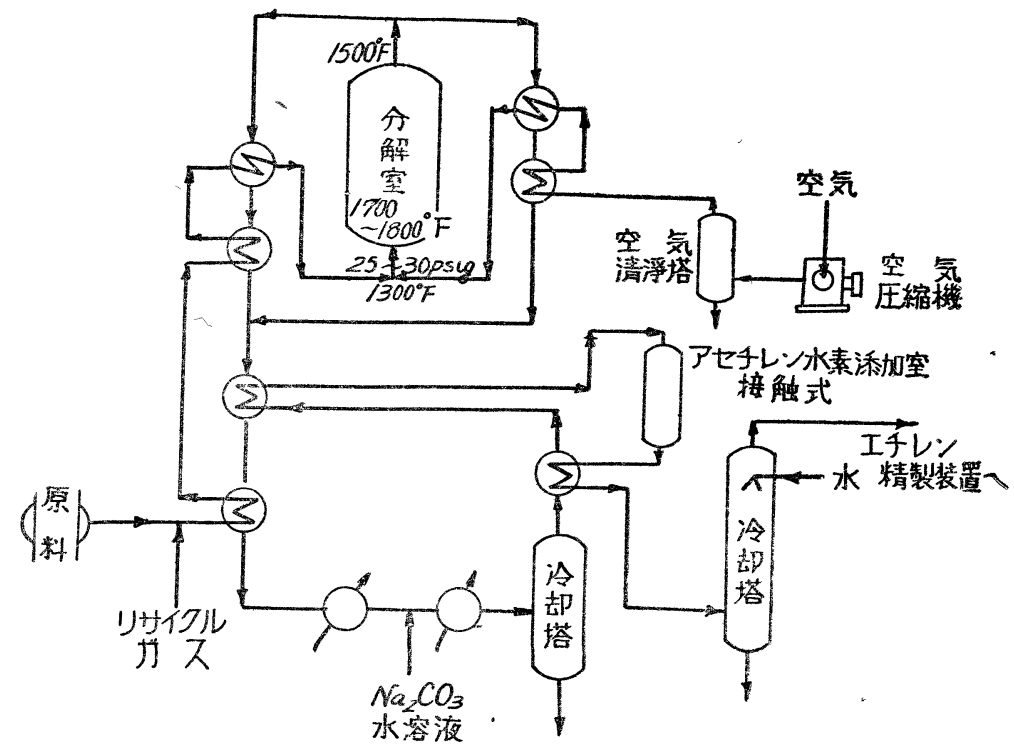

アセチレン聟生量 分解率 痕跡 $50 \%$ $1 / 100$ エチレン $75 \%$ 4〜6/100エチレン $95 \%$

（7）カタロール高溫分解法 本法は，第二次大戦中英国 において, Dr. Chaim Weizman によつて発明されたも ので，その大略については第 9図に示すと颃りてある。特 徽とするところは，高慍分解 と接触分解と 2 段分解を行つ ている点て岕こことと，分解 物としてォレフィンと芳香族 と両方を同時に目的としてい ることてある。生成物の分析 結果からみれは相当その目的 をはたしているよらてあるが 


\section{第 9 図 カタロール高溫分解法}

Cham Weizmann, Petrocarbon Ltd., Patent.

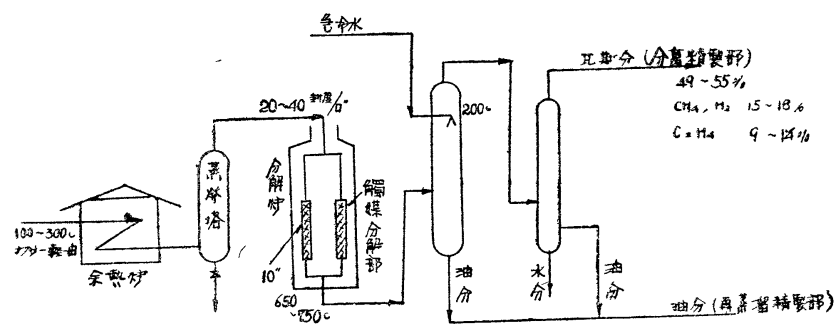

り，パイプを塞ぎ故障を起す原因となる ので水分を除去する必要かある。この目 的のために米国てはグライニール脫水洼 が最も経済的で有効な方法てあると云え られている。その大略については第10四 に示すと扮りである。

その渾枟費については, J.M. Camphell は,アトランティック・シティーに 预ける第 44 回 American Institute of Chemical Engineering Meeting

生成物中に相当量の水素拉よびメタンを含み, 理論と おりに両方のものを同時に製造することの無理てある ことを示していて，將来相当改良を要するよらに思ら。

\section{（V） 分解ガス睆水法}

各分解法に示したとおり, 相当量の水蒸気を使用与 るかまたは酸素を使用するため, ガス中には水分を含 さのか潽通である。分離作業中, 低溫高圧操作を繰迈 すためこれらの水分がガスと共にハイドレイトをつく

\section{第10図 グライコール眖水法}

Hantıngton, "Natuıl Gas \& Natu"al Gasoline"

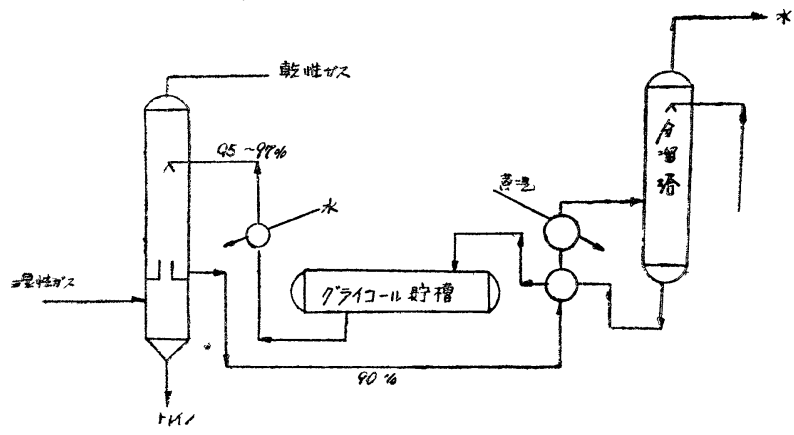

の席上， 0.20 七ント $/ 100$ 万 $\mathrm{ft}^{3}$ 程度てあると述べてい ることを附記してふく。

\section{(VI) エチレン分離法}

$\mathrm{C}_{3}$ 以上の炭化水素の分離は比較的に機械的困䧼性 は少ないが，エチレンの分離はその物理的性質からみ て容易ではないことを第13表で示すこととする。

\section{（1）低溫高圧炭化水素分離法}

最も古く一般的なものて，その技術は既にわが国に も探用されているものであるか，その大略を 第11図に示す。

表で見ると抢りメタン塔その他の作業條件 からみて裝置の材質的, 作業的の困䧼性が相 当あるものの上らな感じがある。またメタン 塔に怙けるェレンの減耗喲 $2 \%$ 近く生す ることは此を得ないすののよらである。

\section{（2）低溫吸收分離法}

本法はダゥ・ケミカルなどで探用されてい るものてつて，その大略は第 12 図のとおり である。低溫高圧法に比して作業溫度か比較 的に高く作業上も割合に経済的のもののよ 5 てある。吸收郕として使用しているものは芳香族なよ

\section{第11図 低溫高圧炭化水素分離法}

Pratt \& Foskett, T' ans. Amer. Inst. Chem. Eng., 42, 149 (1946).

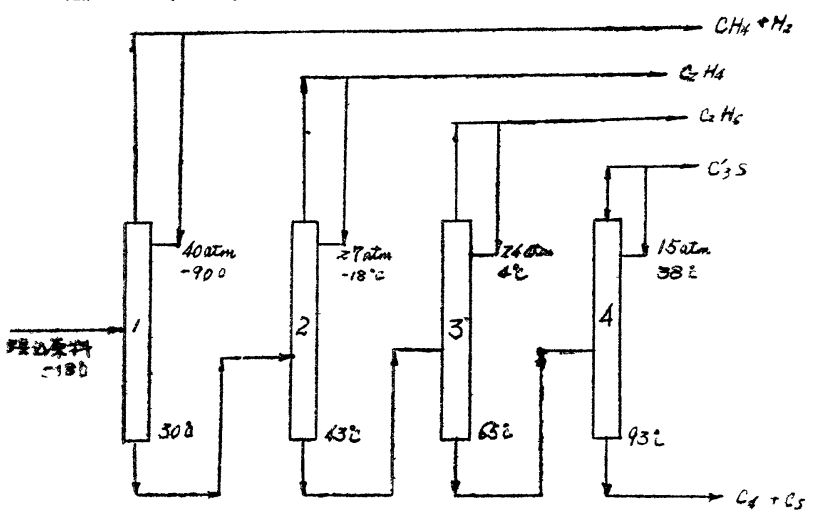


第12図 低溫昅收分離法

L Kniel, W. C. Slager, Pet. Pıgr ess, Oct. (1947)

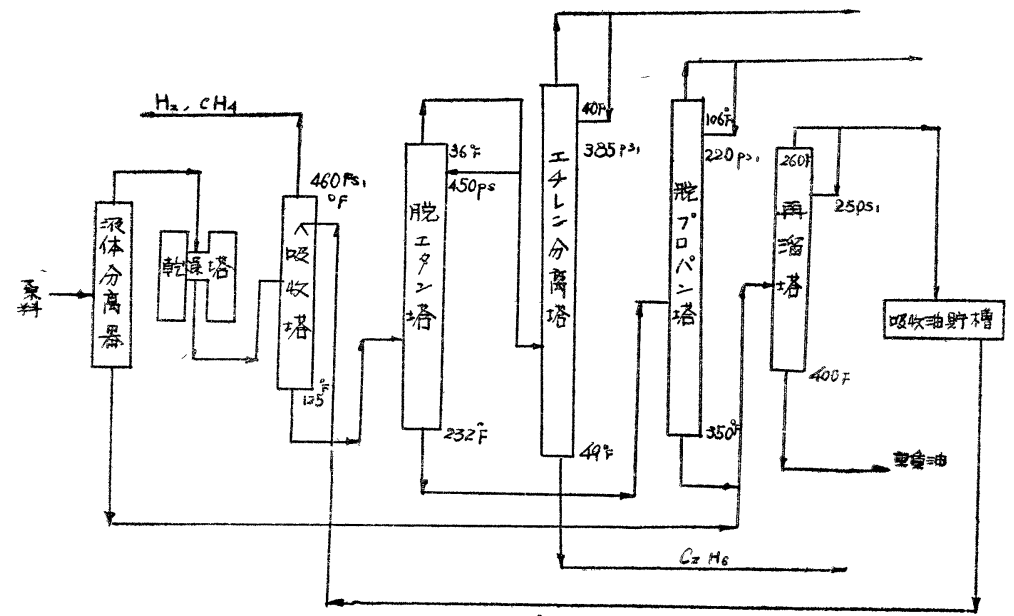

本法はオレフイン系化合 物力容易に硫酸と化合物を つくることを利用せんとし たものであつて, その條件 なとについては第14四の と抢りである。但し，常識 的に考究てみても, 硫酸と オレフインの化合する場合 種々の反応の起る可能性か: 大きいために，奏裝置とし ての価值については相当研 究の要があると思われる。

（5）無機壏による吸收分 離法

銅監による硫化水素, 一 酸化炭素の分離の可能性か

びパラフィン系炭化水系混合物てめつて，吸 收荅に㧍けるェチレンの減耗はわずかに $1 \%$ 强てあることなとは將来この方面の研究の面 白さを物語つているものと考えられる。

(3) ハイパー・ッープション・ェチレン

分離法

本法はフォスター・ホイラー会社て建設,

第14図 硫酸吸收法によるオレフイン分離

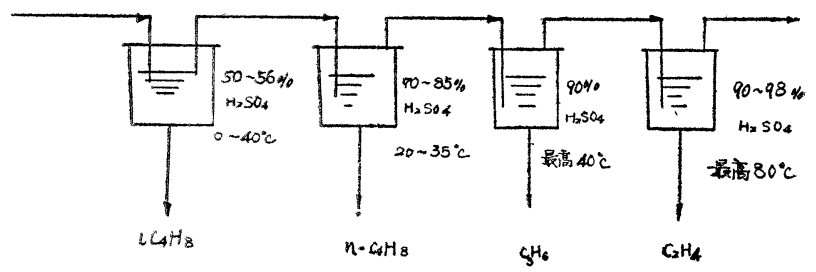

\section{第13図 ハイパソープション・エチレン分離法}

Clydeberg, Refiner, Sept. (1951)

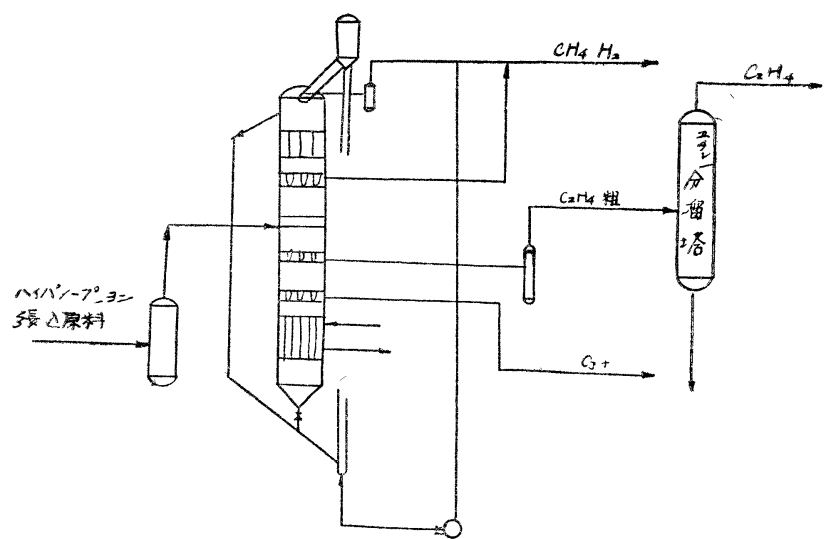

らウインクラーその他のものによつてトイッ で研究をはじめられたものてある。第 15 表 に示すと抢り, ェタノール・アミン, 确酸銅 アンモニア混合液か最もェチレン分離に有効 てあるといわれている。

報せられるところによれは，ドイッの実裝 置で，この方法を探用してプロパン分解より 得られる分解ガスから純度 98〜99\%の土チ レンを製造することができたとのことで，こ の方法の有望性を物語つている。

\section{（VII）エチレン固定法}

前記各種の方法て分解，分離されたェチレ ンは，そのままてはガス体であるために輸揆 の困難がるのて，商品洒值は少ない。商品 としてはこれを液体として輸送に便利にする必要が る。そのためには, クロロハイドリンを経て酸化ェチ レンとする方法, 硫酸化合物をつくりこれを加水分解 してアルコールとする方法，または触媒を使用して塩 素化して笽化ェチレンを製する方法なとが考えられ る。そのいずれを探るかは作業, 取扱いの難易, 需要 の有無，その他経済的事情を充分研究してそのいすれ
発澾しているものて大略は第13困に示すとおりであ， る。紹介によると，本法は非常に融通性の多い有利な ものて岁るといわれているが，詳細な作業條件，吸着 绪として使用される活性炭の物理的性質なとについて 不明のため，筆者にはこれを批評，紹介するだけの智 識かないのて，この程度て說明を終ることとする。

（4）涾品吸着分離法 
第15表 エタノールアミン，硝酸銅アンモニア液によ るオレフイン分離

Haenber \& Hangen, Oppaw Labuatu»

I. G. Report, July 27 (1942).

性質

\begin{tabular}{|c|c|c|c|}
\hline \multirow{3}{*}{\multicolumn{3}{|c|}{$\begin{array}{l}\text { 比重 }\left(20^{\circ} \mathrm{C}\right) \\
\text { 粘 度 }\left(20^{\circ} \mathrm{C}\right) \text { エングラー度 } \\
\text { 表面强少 }\left(20^{\circ} \mathrm{C}\right)\end{array}$}} & $-1.37 \mathrm{~g} / \mathrm{cc}$ \\
\hline & & & 1.86 \\
\hline & & & 687 dyne/cm \\
\hline 比 蓺 & & & $051 \mathrm{cal} / \mathrm{g} /{ }^{\circ} \mathrm{C}$ \\
\hline 初沸点 ${ }^{\circ} \mathrm{C}$ & & & 100 \\
\hline 析出点 (結晶) ${ }^{\circ}$ & & & -30 \\
\hline $\begin{array}{c}\text { 理論的オレフイン } \\
\left(\mathrm{Cu}^{+} \text {量を基本 }\right.\end{array}$ & $\begin{array}{l}\mathrm{CO} \text { 深 } \\
\tau)\end{array}$ & & 75.0 \\
\hline \multicolumn{4}{|c|}{$20^{\circ} \mathrm{C}$ K扣りる $100 \mathrm{cc}$ 当り溶解量 (容量 $\mathrm{cc}$ ) } \\
\hline ヴーチ圧力 atm & 0 & 5 & 10 \\
\hline $\mathrm{C}_{2} \mathrm{H}_{4}$ & 22.0 & 52.5 & 59.0 \\
\hline $\mathrm{C}_{3} \mathrm{H}_{6}$ & 8.0 & 27.0 & - \\
\hline $\mathrm{nC}_{4} \mathrm{H}_{8}$ & 60 & 125 (2atm & - \\
\hline${ }_{1} \mathrm{C}_{4} \mathrm{H}_{8}$ & 1.0 & $2.0(1 \mathrm{~atm}$ & - \\
\hline $\mathrm{CO}$ & 387 & 55.9 & 64.7 \\
\hline $\mathrm{CH}_{4}$ & - & - & $\begin{array}{c}04 \\
1.6(50 \mathrm{~atm})\end{array}$ \\
\hline
\end{tabular}

かを選がべきであるそのおの打のの製造方法などに いては，合成部門のこととなるためここでは略す こととする。

(VIII) 結 言

以上をもつてェチレンを製造する方法の紹介を終る こととするか，わか国に打いて事業的に成立の可否を 考える場合，これを技衍面からみた場合の三，三の点 について、参考むでに箨者の意見を加えて結びとする。

原料については，分解生成物括よびその他作業面か らはてきるたけ低分子量のものを選ぶとしても， $\mathrm{C}_{3}$ $\mathrm{C}_{4}$ 程度の液化力 スを使用寸るのか良いと思う。いま 仗りにクラキングカスが $500 \mathrm{ft}^{3} / \mathrm{bbl}$ そし，その比重を 1 とみて第 1 表の組 成を有するるのと仮定した場合 $\mathrm{C}_{3}, \mathrm{C}_{4}$ の合計量は約 $254 \mathrm{lb}$, bbl となる。これ らの回收率を仮りに $80 \%$ とすと,そ の量は約 201b/bb1 とみることかててき て，この中ェチレンの分解收量を20重 量\%とすれは $41 \mathrm{~b} ; \mathrm{bbl}$ となり，ガス分 離の回收率を $90 \%$ とすれは，約 35 1b/bbl とみることか可能である。国内 製油所で $4,000 \mathrm{bbl} /$ 日の分解裝置の操 業の可能性は多分にあり, 4,000bbi/日
の裝置かあれは約 6t/日のエチレン䡛造か可能てせつ て，原料的には充分成立し得るものてある。

次に資本的に考光た場合, 1946年現在としてネルッ ンは

$$
\begin{array}{lr}
3,000 \mathrm{t} / \text { 年 } & 550,000 \$ \\
2,000 \mathrm{t} / \text { 年 } & .420,000 \$
\end{array}
$$

の建設費を要すると迹へている。おスマンは20〜25 $\$ / 1 \mathrm{~b}$ (製品)/日の建設費を要すると迅へ，そのらち刀 ス分離裝置に $2 / 3$ の費用を要し，軽質原料の有利性を 迌へてている。カーン抢よび八チッンは重要装置の建設 には単位当り製油裝置の約 3 倍を要し,水, 電力゙方の他 附帯副資材は約 10 倍を要するといつている。これら の点からみて, 石油化学工業の規模は製油業に此して 小さいため一工場としての投下資本は想像するほと警 くようなものてはないので,この点もまたかなりの可 能性かある。裝置の大きさによる運転費並びに建設費 の比較を行らために, 経舒式から算出したものとして 第15四を示す。いま仮りにある基準のものに比較して 5 倍の大さのものを建設した場合，その単位能力に対 する建設費も運耺費も共に $60 \%$ てすむから，あまり 型式の小さなものの起設は不利てある。

米国に打ける利閏性とわか国の場合の比較基本とす るために，第16表て石伷化学製品と石油製品の運貢 比較を行つた。これてみると，石油製品に対して石油 化学製品は 2 倍の運賃を要しているが，製油事業は製 品と原油のわすかな運賃差て相当国家的に有利な事業 であることは衆人の認むるところてあるから，この点 あまり心配を要しない。

なお，事業のスケールについては，米国の製油業は 本均一工場当り $30000 \mathrm{bbl} /$ 日に封し，わが国ては $10,000 \mathrm{bbl} /$ 日程度の規模になりつつあることを，石油 化学工場の単位の大きさを考兊る際の資料とするのも

\section{第15図 設借のきたなさによる建設費並びに逞転費の比較}
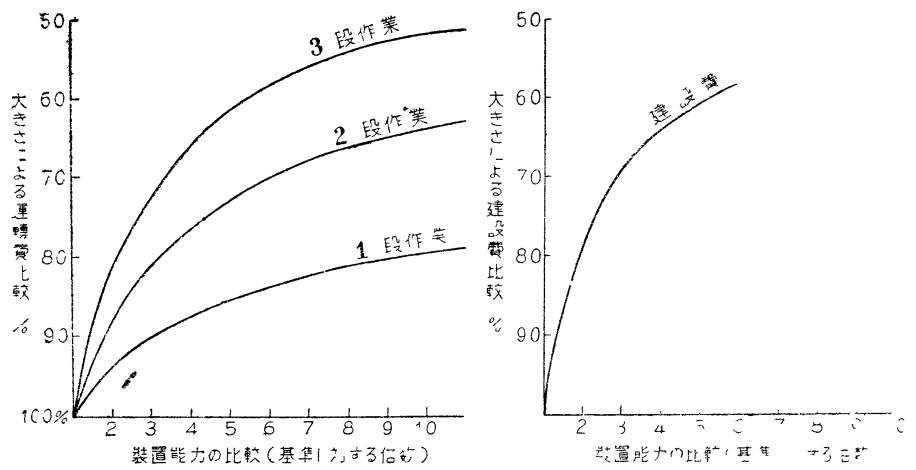


\section{第16表 米国における代表的石油製品および石油化学製品の $1001 \mathbf{b}$ 当りの鉄道運賃率}

W. E. Kuhn \& J. W. Hutcheson, Chem. Week, Sept. 29 (1951).

\begin{tabular}{|c|c|c|c|c|}
\hline & $\begin{array}{l}\text { Houston から } \\
\text { New Yorkま }\end{array}$ & $\begin{array}{l}\text { Houston活 } \\
\text { Pallas まで }\end{array}$ & 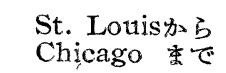 & $\begin{array}{l}\text { St. Louis } \\
\text { New Yor }\end{array}$ \\
\hline 距 離 マ イ ル & 1780 & 305 & 276 & 1040 \\
\hline 石 油 慗 品 & & & & \\
\hline 液 化石 油少“ & $\$ 1.39$ & $\$ 0.41$ & $\$ 0.44$ & $\$ 1.11$ \\
\hline ガ ソリン & 1.11 & 0.38 & 0.31 & 0.79 \\
\hline 溜 出 燃 料 油 & 0.92 & 0.38 & 0.24 & 0.73 \\
\hline 䇅 椬 " & 0.92 & 0.38 & 0.24 & 0.73 \\
\hline 算 術 本 均 & $\$ 1.08$ & $\$ 0.39$ & $\$ 0.30$ & $\$ 0.84$ \\
\hline 石 油 化 学 製 品 & & & & \\
\hline 酸 化 $夭$ チ & $\$ 2.87$ & $\$ 0.97$ & $\$ 0.68$ & $\$ 1.41$ \\
\hline トリエタノールアミン & 2.44 & 1.08 & 0.68 & 1.38 \\
\hline エチレングリコール & 1.45 & 0.61 & 0.42 & 1.33 \\
\hline レイョン繊維をたは糸 & 2.44 & 1.08 & 0.93 & 2.07 \\
\hline 算 術 本 均 & $\$ 2.30$ & $\$ 0.93$ & $\$ 0.68$ & $\$ 1.55$ \\
\hline
\end{tabular}

一つの考え方である。

米国における石油化学の利潤を示すものとして第17

表を示す。奏收はほぼ石油精製業と近いもののよ5で せるが，その研究費などは製油業の約 3〜4 倍を費し

\section{第17表 米国における化学会社および石油会社の実收および利閏}

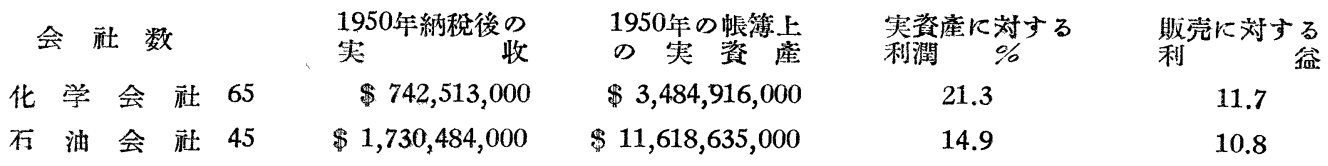

て日進月步の進步を行つているとのことである。研究者の各位に今後の指導並びにご敎示のほどを併せ 以上，はなはだ概念的說明に終つたが，一技術者の 立場から金融関係並びに事業经営者であられる先輩各 位ぶ石油化学工業に関する認識を新たにされて一日も 早くわが国にこの種工業の健全なる発達の途を閶かれ んことを願つてやまない次第である。また学者並びに て嫄いして，この稿を終ることとする。な颃本稿執 䇣の自由を許された三菱石油株式会社街長はじめ会社 の幹部各位と資料の準備その他に協力くださつた会证 の同僚に深甚の感謝をささげる次第である。

\section{Olefin Preparation from Petroleum}

\section{By Takezō Obata}

(The Mitsubishi Oil Co.)

SYNOPSIS :-The author reviewed the works of ethylene preparation by petroleum decomposition, especially of the methods for dehydration and separation of ethylene from the decomposed gases. He also asserted that the petroleum chemicals' industry must have wider future in this country, hoping its quick development. 